\title{
Transnationalism and the Resistance from Below
}

\author{
Yadav Raj Panta, PhD \\ Lecturer, Bishwa Bhasha Campus, Tribhuvan University. \\ Email for correspondence:ypantayp@gmail.com
}

\begin{abstract}
This research article focuses on the deciphering of the various facets of transnationalism thereby opening up the avenues for the discussion of the resistance from below. Whether or not the transnationalism would support the resistance from below or resist the resistance from below is the concern of debate. However, the result of transnationalism causes the cultural fluidity and the hybridity in every aspect of life- be it cultural, political or economic. When transnationalism is defined as the tool for the global capitalism, the resistance from below could be eroded and sidelined. There, the relations are not as clear as one expects them and not as opaque as we assume them to be.
\end{abstract}

Key words: Transnationalism, global capitalism, subversion of the binary and celebratory practice.

\section{Context}

The age long nationalism's agency in the identity formation process of an individual has been questioned with the introduction of transnationalism at present. Transnationalism brings the fluidity out in identity by rendering the failure of nationalism's morphologies. Technology, global capitalism, multiculturalism, transnationalism from above and below, etc. bolster transnationalism in this project of dismantling the nationalism's ground for identity. Stepping on globalization and the crisis of the nationstate, transnationalism encourages the global and local forces to penetrate the national cultural and political systems. Global forces act in form of transnationalism from above and penetrate the national morphologies while local culture acts from below and resists the global forces. In these both process, the national morphologies along with national territory are challenged and dismantled. Luis Eduardo Guarnizo and Michael Peter Smith in "The Locations of Transnationalism" observe the weakening position of nation-state and wrote, "The nation-state is seen weakened from above by transnational capital, global media, and emergent supra-national political institutions. From the below, it faced the decentering local resistances of the informal economy, ethnic nationalism, and grassroots activism" (Guarnizo \& Smith, 1998, p. 3). For market policy, it can be something celebratory practice but at the same time it creates a cultural hybridity. In more pessimistic readings, these developments are seen as preludes to a new form of capitalist modernization that is bound to convert the entire planet to global consumerism.

Transnationalism is widely conceived celebratory in a sense that it subverts the popular resistance from below. Luis Eduardo Guarnizo and Michael Peter Smith point out this aspects of the response of people to transnationalism when they write, cultural hybridity, multi-positional identities, border-crossing by marginal others, and transnational business practices by migrant entrepreneurs are 
depicted as conscious and successful efforts by ordinary people to escape control and domination "from above" by capital and the state" (Guarnizo \& Smith, 1998, p. 5). Transnationalism is a result of globalization and is caused by the resistance from the below where the commoners/local forces come to challenge the forces of globalization like capitalism and cosmopolitanism.

Transnationalism thrives in the dissolving of the national cultural and territorial boundaries. Thus, it attacks on the deceptive local-global binaries. Such subversion of the binary often depends on the formation of the political organization of transnational space; the constitution and reproduction of transnational networks through material and symbolic exchange; transnationalism and identity politics etc. Examining these major factors of transnationalism, Luis Eduardo Guarnizo and Michael Peter Smith define transnationalism as "a multifaceted, multi-local process. A main concern guiding Transnationalism from Below is to discern how this process affects power relations, cultural constructions, economic interactions, and, more generally, social organization at the level of the locality" (Guarnizo \& Smith, 1998, p. 6). Removing the ground of binary of local-global from under the feet of nationalism, transnationalism blurs such binary thereby defying the cultural and territorial boundaries. All the power construction and the development of the systems of the nation should be discerned by focusing on the resistance of such systems from the below.

Transnationalism's socio-cultural aspect may accompany with the global capitalism. Both modes of transnationalism as abstract i.e. socio cultural and sometimes as materialistic i.e. global capitalism come together or separately. Nonini and Ong in their article "Chinese transnationalism as an alternative modernity" are critical about the creeping dilution of research by a cultural studies approach "that treat transnationalism as a set of abstracted, dematerialized cultural flows, giving scan attention either to the concrete, everyday changes in people's lives or to the structural reconfiguration that accompany global capitalism" (Nonini \& Ong, 1997, p.13). Transnationalism is neither a pure dematerialized cultural flow alone nor solely the materialistic global capitalism. It occurs on both cultural and economic levels.

However, transnationalism is not as clear and opaque as people think it to be. There are complex structures and ties of it which cause the differences in its forms. The rapid form of change in peoples living around the world which apparently differs from the territory and national culture bound living, is generally represented by transnationalism. Nancy Foner puts it, "some groups [and places] are likely to be more transnational than others and we need research that explores and explains the differences in which within immigrant groups, there is also variation in the frequency, depth and range of transnational ties" (Nancy, 1997, p. 23). Foner pointing to this complex nature of transnationalism here seriously expects people to realize the vast terrain of transnationalism. Transnationalism has its own methodology to understand the multiple sites of activities including concrete/material, abstract, and cultural. In other words, it can be termed as the multi-sited ethnography which offers a good space for researchers to study transnationalism. "This method", as George E. Marcus in "Ethnography in/ of the world system: the emergence of multi-sited ethnography" argues, "involves tracing a cultural formation across and within multiple sites of activity' by way of methods 'designed around chains, paths, threads, conjunctions, or juxtapositions of locations” (Marcus, 1995, p. 105). This method revolves around the different aspects like chains, paths, threads, and conjunctions etc. as parts of the national morphologies to complicate the cultural and territorial locations of the nation. 


\section{Contextualization}

Coming across all these definitions by different thinkers, transnationalism as a movement has got its impetus on material or economic expansion that either from above or from below happens to blur the boundaries created in nation. However, the extended use of transnationalism at present has got a lot to do with the socio-cultural issues creeping across such national territories or morphologies. Such kind of subversion of national territory or morphologies is possible only when one finds out the weakening effect of nationalism that leaves a space for transnationalism to get introduced in both economic and cultural factors which directly determine the identity of the people.

The foremost weak point of nationalism is that it survives by suppressing almost all the threats posed to it from globalization, transnationalism, post-nationalism, diaspora etc. Secondly, nationalism is always in flux receiving challenges from the advancing technologies. Furthermore, the growing trend of dismantling of the hierarchies directly does attack the binary's ground to the nationalism. Nationhood's sense", as Paul Giles urges in his article "Transnationalism and Classic American Literature", "emerges from a negotiation with and partial suppression of transnational frictions and disturbances" (Giles, 2003, p.66). He further adds, "[the] conception of the nation-state tends[s] to remain, characteristically, in flux" (Giles, 2003, p. 68). The identity in its essence is filled with fluidity but nationalism tends to suppress the heterogeneous aspects of identity in order to solidify the single/absolute identity. In fact, nationalism relies on a very weak ground created by homogenization of the diverse aspect of a nation-state. On defining nationalism as a product of totalizing tendency of a nation, we can question the identity created by such nationalism. Transmigrates' narrative counters the boundaries set by nationalisms and further exhibits the rift in nationalism's essentialist identity. Such weak position of nationalism is weakened further by technology. Technology on the other hand mocks the national morphologies especially the communities/boundaries by creating a space for new kind of fluid identity i.e. transnational identity. Giles in his article "Transnationalism and Classic American Literature" finds technology responsible for the loss of nation's control over identity. He has written, "Nations have lost their old omnipotence, the invention of new technology is rendering national communities obsolete. Nations have lost their old omnipotence. [We] go and live where we will" (Giles, 2003, p. 68). This loss of nation's control over identity has loosened in people the sense of belongingness to certain territory and culture. They feel free to move anywhere they like and adopt the identity temporarily.

Similarly, the support from conflict and war to the technology has helped a lot in this project of dismantling the hierarchy of local and global. Giles argues, "how the geographies associated with different cultural identities "have always overlapped one another, through unhierarchical influence, crossing, incorporation, recollection, deliberate forgetfulness, and, of course, conflict" (Giles, 2003, p. 72). Overlapping of the cultural and geographical identities ultimately dissolves the territories and results into a fluctuation in identity. Hierarchy doesn't function any longer due to the crossing of cultural and national morphologies along with the forgetfulness of the people. They mix up morphologies easily and accept the newly formed identities time and again. The theme of nationalism comprises of a basic theme of family and friendship which occurs through the exchange of goods, people and resources. The 
post-colonial cultures transfer and mimic images of other cultures which for Jameson, as Karen Har-Yen Chow concludes, it is a late twentieth century postmodern culture. Chow in his article "Asian American Transnationalism in John Woo's Bullet in the Head writes, “As Fredric Jameson argues, late twentieth century postmodern culture is one of simulacra which are reproducible and which often render the original image untraceable" (Chow, 2000, p. 381). Simulacra ultimately dismantle the theme of family and friendship thereby dismantling the theme of nationalism as well. Articulations of cultural nationalism, also couched as ethnic nationalism, are enacted within but also outside of nation. Technology on the other hand plays a vital role in dismantling the fore mostly important element of nationalism that is its territory. The Study of Transnationalism: Pitfalls and Promise of an Emergent Research Field argued, though lacking the contemporary technologies of communications and transportation, precursors of present immigrant transnationalism have existed for centuries but few immigrants actually lived in two countries in terms of their routine daily activities (Portes, Guarnizo \& Landolt, 1999, p. 224). While most dreamed of going back one day, this long-term goal was countermanded by the concerns and needs of their new lives and, for many, eventually faded away.

Technology also creates a culture of its own that counters the traditionally solidified definition of culture. This newly formed culture is strictly in a bond to globalization and flows with it thereby contaminating the nationalism that grounds on the traditional cultural practices. Gayatri Spivak's 'Who claims alterity?' describes the discourse of cultural specificity and difference, packaged for transnational consumption through global technologies, particularly through the medium of 'microelectronic transnationalism' represented by electronic bulletin boards and the internet (Gayatri, 1989, p. 276). Technology, as Spivak believes, forms a microelectronic transnationalism through cybernetics which obviously carries the nation beyond nation or brings the out inside nation. Blurring of such cultural and territorial boundaries ultimately puts threats on nationalism.

\section{Conclusion}

This research paper has the major thrust of attempting to examine the multifaceted transnationalism as the tool of necolonization- global capitalism. When the national territories are forgotten while talking about economies and culture, the effect of globalization is clearly felt. The resistance from below sometime becomes effective while the other times, such resistances are quite negligible.

\section{References}

Chow, K. H.Y (2000). Asian American Transnationalism in John Woo's Bullet in the Head". Journal of Narrative Theory, 30 (3), 364-384.

Gayatri, S. (1989). Who claims alterity (269-292)? In Remaking History (pp. 269-292) (B. Kruger \& P. Mariani, Eds.). Bay: Seatle.

Giles, P. (2003). Transnationalism and Classic American Literature. PMLA, 118 (1), 62-77.

Guarnizo, L. E. \& Smith, M.P. (Eds) (1998). The Locations of Transnationalism: Transnationalism from Below. New Brunswick: Transaction Publishers. 
Marcus, G. E. (1995). Ethnography in/of the World System: The Emergence of Multi-suited Ethnography. Annual Review of Anthropology 24, pp.6-23.

Nancy, F. (1997). What's new about transnationalism? New York immigrants today and at the turn of the century. New School of Social Research. New York: Transnational Communities and the Political Economy of New York.

Nonini, D. M. \& Ong, A. (Eds.) (1997). Chinese Transnationalism as an Alternative Modernity Ungrounded Empires: The Cultural Politics of Modern Chinese Transnationalism (pp.3-33). London: Routledge.

Portes, A., Guarnizo, L. E. \& Landolt, P. (1999). The Study of Transnationalism: Pitfalls and Promise of An Emergent Research Field. Ethnic and Racial Studies, 22 (2), 217-237. Routledge. 